\title{
Exploring Peer-to-Peer Library Content and Engagement on a Student-Run Facebook Group
}

\section{Kaya van Beynen and Camielle Swenson}

\begin{abstract}
Student-run Facebook groups offer librarians a new means of interacting with students in their native digital domain. Facebook groups, a service launched in 2010 enables university students to create a virtual forum to discuss their concerns, issues, and promote events. While still a relatively new feature, these groups are increasingly being utilized by students in universities and colleges throughout North America. Little research has been done on these groups and how they may be changing the way that students interact with each other and with their university on social media. A student-run university Facebook group was monitored for a year to measure library content and types of engagement. The purpose of this research was to systematically explore whether outreach to these new virtual forums are of value to librarians in term of effort and outcome, and to provide research-based insight into the best practices for librarians when confronted with similar unofficial student-run Facebook groups. Our findings suggest that library employees strategically focus on key periods during the semester and use photographs and contests to increase virtual engagement and spontaneous in-library event participation. Students used the Facebook group both as a source for library information and to thoroughly answer their peers' general library questions; when confronted with more research-based questions, the students referred each other to the library for help. We conclude, that library outreach on a student-run university Facebook group is manageable and can complement in-house marketing and reference efforts.
\end{abstract}

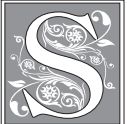

ince its inception in 2004, Facebook has been a popular networking tool on college campuses. An estimated 85 percent of college and university students in the United States now have a Facebook profile. ${ }^{2}$ Students primarily use Facebook for nonacademic purposes such as connecting with friends, family, and online communities, increasing their social capital, and sharing images, videos, and other forms of digital entertainment. ${ }^{3}$ The students perceive Facebook as "fun," and generally report being uncomfortable with the idea of merging their academic and personal lives on social media sites. ${ }^{4}$ Professors particularly suffer in this regard, as past studies find that students don't want professors intruding

Kaya van Beynen is an Associate Librarian and Camielle Swenson is an Instructor Librarian in Nelson Poynter Memorial Library at the University of South Florida St. Petersburg; e-mail: kayatown@usfsp.edu, csswenso@mail.usf.edu. (C) 2016 Kaya van Beynen and Camielle Swenson, Attribution-NonCommercial (http://creativecommons.org/licenses/by-nc/3.0/) CC BY-NC. 
on their personal lives or knowing what they were saying about courses, teaching, or assignments. ${ }^{5}$

With many library Facebook pages, questions abound whether they are actually where their users are and whether they are useful to the university students. ${ }^{6}$ By 2011 , the Association of Research Libraries (ARL) found that 90.4 percent of ARL libraries had a Facebook page. ${ }^{7}$ Asking students whether they would "like" a library webpage, Connell found an ambivalent response: 17 percent of students would proactively ask a library to be their friend, 58 percent said they would accept a library profile friend request, while 25 percent of the students reported that they would never connect with the library on Facebook. ${ }^{8}$ Two years later, a study by Sachs, Eckel, and Langan found more optimistic results, with over two thirds of the Western Michigan University (WMU) student population willing to "like" or "friend" the university library Facebook page. ${ }^{9}$ In reality, as an outreach tool, university library Facebook pages still have a long way to go; in the ARL study, 36 percent of the library Facebook pages had fewer than 100 fans and 31 percent had between 100 and 200 fans. ${ }^{10}$ Furthermore, the authors suspected that many of these fans were actually fellow librarians or colleagues at other libraries rather than the student population that they desired to reach.

University libraries primarily use their Facebook pages to market events, resources, and services and to answer general library questions. ${ }^{11}$ Library Facebook pages can increase a library's visibility among the student population, raise awareness of the library services, and try to instill a friendly and approachable image among their user population. ${ }^{12}$ Yet librarians have not been as successful using Facebook as a forum for reference assistance. Jacobson found that librarians' perception of their use of Facebook for reference services was higher than the actual use. ${ }^{13}$ Students reported being comfortable receiving library information, but they were unlikely to use library Facebook pages to ask for research help. ${ }^{14}$ Additionally, many university students are unaware that their academic library may offer reference service on Facebook. Even when the students do use Facebook to ask a reference question, the response might be a referral to a librarian or to a virtual reference service, or they do not receive a sufficiently timely response. ${ }^{15}$ With these referrals and nonresponses, the students quickly were discouraged from using library Facebook pages for reference assistance.

With continual technological changes, it is crucial to make sure libraries allocate an appropriate amount of staff time and energy to manage their social media initiatives. ${ }^{16}$ The actual value of the academic library Facebook initiatives, in terms of contributing to the library mission, and just how much library energy should be extended on this front is still in debate. The most common metrics of library Facebook outreach are the total number of library Facebook page likes (a measure of audience reach), the number of posts, and the associated feedback in the form of likes and comments on the posts (measures of engagement). ${ }^{17}$ How many likes or fans a library page has is affected by how long the page has been in existence, page awareness, and quantity and quality of the content. The number of posts, with their associated likes and comments, indicates whether the fans have actually seen and somehow interacted with the information.

But these measures of Facebook audience and library outreach are problematic. Chiu and Lin found that 92.7 percent of posts on a library Facebook page were made by the library staff or faculty and not the actual students. ${ }^{18}$ Although the number of likes and comments fails to capture the impression of the post, as in how many people actually viewed it, it does capture the level of engagement, which could be argued as being of more importance when considering library staff investment in Facebook. ${ }^{19}$ Engagement on library Facebook pages was also low; the vast majority of posts (63\%) did not have any likes or comments at all. ${ }^{20}$ Both studies found that likes were more common than comments and primarily come from the library staff and faculty. Likes, 
although more common, can be considered somewhat less valuable than comments; they express a level of interest but do not add to the conversation. Facebook posts with photographs tended to have more feedback than other posts.

Looking beyond these quantitative measures, Chiu and Lin did a content analysis of the Facebook posts, differentiating between the types of information (advertisement, multimedia broadcasting, library policy, reference, and so on) and the types of participation (asking questions, posting controversial comments, response from libraries, and the like). ${ }^{21}$ Advertisements of library events were the most common type of information posted. They found that only one academic library out of the 10 surveyed specifically provided Reference Services on Facebook; however, with a closer examination of the types of information shared on the library Facebook pages, the story slightly changes. For example, classification of posts included Book Advice (12.13\%), Library Catalog (.05\%), Library Policy (1.58\%), Posts from Fans and Friends $(7.01 \%)$, and Reference Services (.05\%). Examples for all of these categories are questions on library services, resources, policies, and research help. Thus, while Reference Services is only a minuscule category, it is not clear that these categories specifically meant research help. Altogether, Chiu and Lin's codes for library questions add up to 20.82 percent.

Similarly, Gerolimos did a content analysis of 20 American academic library Facebook pages and distinguished between library-related comments (general info, reference questions, hours, directions, compliments, funny comments, library hardware and software, complaints, and suggestions) from the non-library-related comments (advertisements, hate speech, offensive language, religious/political comments, news, other institutional services). ${ }^{22}$ The majority of the comments were Complimentary (33\%), General Comments about the Library (30\%), and Library-Related Jokes (9\%). Reference questions comprised only 1.26 percent of the library posts, but other categories included questions about Library Hours (1\%), Equipment (1\%), and General Information about the Library (2\%). As such, exactly what the category Reference Questions refers to is unclear, perhaps indicating in-depth research questions as distinct from the other more general questions on library information and technology. Gerolimos characterized the library Facebook pages as having low numbers of followers mostly made up of library employees or colleagues and few interactions between the library and university students except for infrequent spikes in feedback from library posts with pictures or video content. As a marketing tool, Gerolimos concludes that Facebook is not a worthwhile expenditure of library staff time and effort.

On campuses, Facebook groups created by students provide a forum for students to ask general questions, share knowledge, and discuss topics of interest. Among university students, Facebook groups might be a small study group, all the students of a particular graduating year, a student academic or extracurricular club, and many other possible connections. Facebook groups with a narrow focus tended to have a smaller membership and were less active in terms of number of posts, likes, or comments. University Facebook groups with a broader focus and a more diverse university population (including university students, staff, and faculty) tended to have a larger membership, a larger quantity of posts, and higher engagement rates in terms of comments and likes. The membership of the most successful Facebook groups were primarily students but were also welcoming to staff and faculty. This broad, cross-university membership increased discussion levels, expanded the range of topics, and facilitated a higher sense of community. ${ }^{23}$

While Facebook groups are a relatively recent feature, they have become widely adopted by college and university students throughout the world. Examples of unofficial student-run Facebook groups can be found for the University of Texas Arlington (https:// www.facebook.com/UnofficialUTA) and Ferris State, Michigan (https://www.facebook. 
com/...University-Student-Group/1181542616195...). Other university student Facebook groups gather by graduating year; for example, the Wake Forest Class of 2015 (https:// www.facebook.com/...University-Class-of-2015), the University of Boulder Colorado Class of 2016 (https://www.facebook.com/MyCUBoulder2016), or the Class of 2017 at the University of Washington (https://www.facebook.com/Huskies2017). At colleges and universities throughout the United States, students are creating, joining, and engaging in these unofficial student-run Facebook groups. As such, academic librarians need to develop some sense of this phenomenon and its bearing on academic librarianship, which this study begins to do.

\section{Study Context}

In this article, we investigate a student-run Facebook group called the USFSP Know It All Guide to Knowing It All (hereafter referred to as the Know It All Guide) at the University of South Florida St. Petersburg (USFSP). The Know It All Guide was created in 2011 by a student government president to increase campus communication and to raise student awareness and use of university and student services. ${ }^{24}$ Any member of the Know it All Guide can "invite" another member to join the group; and, from the very beginning, USFSP faculty and staff were encouraged to join and contribute to the group. While the group membership is not restricted to USFSP students, staff, and faculty, its singular focus on USFSP generally limits the membership to individuals within this community. Any member can post an item on the group wall, and common topics range from advertisements of campus events, queries on courses or faculty quality, calls for assignment help, questions on student services, registration, and payments to debates on campus policies, parking, and facilities. Generally, anything pertinent to USFSP is discussed in this Facebook group. Nonmembers are unable to view the group posts or to post and contribute to the group discussion. At the beginning of fall 2013, there were 1,622 members; by the end of the spring 2014 semester, there were 2,244 members. This represents a 38 percent growth rate in group membership during the 8 months of the study period alone. In fall 2013, USFSP had a population of 4,700 students and approximately 500 employees (faculty and staff). As such, approximately 30 to 40 percent of the USFSP community (students, faculty, staff) were members of the Know It All Guide Facebook group.

In the 2012-2013 academic year, the USFSP Webmaster led a series of campuswide meetings to discuss social media and to develop university social media guidelines. At the time, the Know It All Guide was already an active group with a strong virtual presence on campus. At these meetings, many of the university employees debated whether to ignore, passively monitor, or engage in the Know It All Guide. As it was a student-run group and not a formal university entity, many USFSP employees were concerned about the accuracy of the information and the potential liability of USFSP with regard to the comments, particularly anything relating to risks to student health, privacy, and civil discourse. The librarians responsible for marketing and social media were also unsure about the value of their participation and wondered whether the Know It All Guide provided a useful opportunity to directly engage students or whether students would perceive the librarians as trespassing on their native digital domain. Still, the librarians were interested in expanding their outreach and visibility on a forum where so many students regularly connected, but not necessarily to provide reference or become involved in student discussions.

Within this context, a quick outline of various types of Nelson Poynter Memorial Library (NPML) interaction with students is needed. Similar to many academic libraries, the more formal means of interacting include training Resident Assistants (RAs) and campus tour guides, speaking at undergraduate and graduate student orienta- 
tions, and, of course, bibliographic instruction sessions. Still, within a formal confine but situated in a less hierarchal relationship, two librarians serve as faculty advisors to two student groups, and two other librarians serve on student services committees as the faculty representative. The library also partners with several student services departments, such as the TRIO program, the Wellness Center, and academic tutoring. The library does not have a student advisory group but conducts an annual general student satisfaction assessment with both quantitative and qualitative questions as well as other assessments using focus groups and surveys to solicit, track, and benchmark the student experience, perception, and use of the library.

The librarians also engage students in a variety of less formal student/staff/faculty events (such as focusing on university women, student leadership, departmental meet and greet) and the library dean routinely meets with student government representatives, both at their general meeting and through appointments to discuss specific topics of interest. Of course, as this is a generally small campus, the librarians interact with students at the reference desk, and the liaison librarians become familiar with students during their time at USFSP. Finally, the library hires student workers in all of the departments, but most plentifully for the Access Services, Technical Services, and Systems departments. These students frequently become informal intermediaries between the library and the student population.

Marketing of library resources, services, and programming is done through the following outlets: print posters, a campus listserv, rotating TV slides in the library and the University Student Center, articles and advertisements in the campus newspaper, a library news and events page, a newsletter in the toilet stalls, and by encouraging faculty to spread information on library events and activities in their classes. The library has a Facebook page (https://www.facebook.com/PoynterLibrary), which had approximately 300-400 likes during the period of research. While these marketing outlets are frequently used by many academic libraries, better ways of engaging student attention and facilitating participation with the library are always of interest.

\section{Methodology}

This research was a systematic exploratory study using both quantitative and qualitative methods to define the scope and extent of student virtual engagement with the library in their own native digital domain. The Know It All Guide Facebook group was tracked for the duration of the fall 2013 and spring 2014 semesters. The number of members at the start and end of each semester was recorded to help determine the population. The researchers monitored the Know It All Guide daily, searching for references to the library, beginning on the first day of the fall 2013 semester and ending on the last day of spring 2014 semester. These references included posts that were originally and specifically about the library, as well as posts not about the library but containing a reference to the library in the subsequent comments. Data collection consisted of screenshots of the original post and all the ensuing comments. These screenshots, taken throughout the workweek, captured any associated images, the identity of the poster (whether he/she was a student or a library employee), the number of likes and comments, the text of all comments posted, and ensuing discussion. In addition, data on the posting date and day of the week were also collected. Subsequent screenshots were taken to capture any continued dialog on older library-related posts.

Data entry and analysis were done during the 2014 summer semester. Details of the library posts were entered into an Excel spreadsheet with the following categories:

- A transcription of the entry original text

- Whether the original post was by a student or a librarian 
- Posting date

- Posting day of the week

- Total number of likes

- Total number of comments

- Total number of comments referring only to the library

- A transcription of the text of the comments referring to the library

The numerical information from these categories, their likes and comments, were totaled and averaged to generate a quantitative description of our population. We subsequently compared the post engagement (number of likes and comments) by the following variables: fall vs. spring semester; student vs. librarian posts; type of content (text, image, multimedia); and day of the week.

To generate an estimated total level of engagement for comparison, all posts on any and every topic on the Know It All Guide were measured during the last two weeks of the spring 2014 semester. These sample data included the total number of posts and their total number of likes and comments. A full USFSP semester consists of 16 weeks; thus, this two-week sample, multiplied by eight, is our rough estimate of a full semester of the Know It All Guide Facebook activity and engagement.

The next step was a content analysis of the library-related posts and comments. This consisted of coding 321 posts and comments according to two classification systems: 1) the NPML classification scheme (based on Warner and adapted by Henry and Neville); and 2) 6 categories we created to describe the intent of the post or comment and to highlight their unique social media quality. ${ }^{25}$ For both coding systems, the original entry post was coded along with any subsequent library-related comments. To ensure the quality and consistency of coding, each semester's data were initially coded (fall entries by $\mathrm{KvB}$ and spring by $\mathrm{CS}$ ). We subsequently discussed our coding rationale and any problematic entries, revised our coding system, and swapped the semesters to ensure coding consistency.

The Poynter Library Service Desk Classification Scheme is used at the NPML to track all public service transactions in the library. The categories are shown in table 1 below.

The application of this coding scheme let us compare the library questions and comments on the Know It All Guide to those handled at the NPML information desks. We were able to directly compare the proportion of question types (General, Technical, Basic Instruction, and Research). Our second comparison of Know It All Guide library content to the NPML was based on the weekly volume of questions. For this check, we grouped the total number of questions and comments by week and ran a correlation

\begin{tabular}{|l|l|}
\hline \multicolumn{2}{|c|}{ Poynter Library Service Desk Classification Scheme } \\
\hline General/Directional & $\begin{array}{l}\text { library or campus location, supplies, hours, study space, library } \\
\text { policies, quality of library environment, events, referrals, etc. }\end{array}$ \\
\hline Basic Skills & $\begin{array}{l}\text { simple catalog search, how to access remotely, how to renew } \\
\text { online, how to setup ILL, etc. }\end{array}$ \\
\hline Library Technology & General computing issues, printer/copier, local software, etc. \\
\hline Online Technology & $\begin{array}{l}\text { Google Apps, e-mail, portal login issues, netID creation, virtual } \\
\text { apps (apps.usf.edu) }\end{array}$ \\
\hline Distance Learning & $\begin{array}{l}\text { LMS-related (Blackboard, Canvas), course-related chat and } \\
\text { video, etc. }\end{array}$ \\
\hline Research & $\begin{array}{l}\text { help with search strategy, complicated catalog searches, suggest } \\
\text { and/or demonstrate database, etc. }\end{array}$ \\
\hline
\end{tabular}


analysis to determine the existence of any relationship between semester week and the volume of questions.

The second coding scheme was applied to elicit the intent of the posts and comments and to highlight their unique social media quality (methods of communication and participation that cannot be done through other media). These six categories are shown in table 2 below.

\begin{tabular}{|l|l|}
\hline \multicolumn{2}{|c|}{ TABLE 2 } \\
Types of Library Information Posted \\
\hline Multimedia Artifact & $\begin{array}{l}\text { Images, videos, and hyperlinks to blogs and other digital } \\
\text { forums. Posts in this category were frequently news items, but } \\
\text { used social media's unique means of visual and interactive } \\
\text { communication }\end{array}$ \\
\hline Virtual Participation & $\begin{array}{l}\text { Posts indicating online participation (for example linking a } \\
\text { friend's name to a library post), synchronous participation with } \\
\text { in-library events (similar to the news tag, while the event is } \\
\text { happening, rather than an ahead-of-time flyer or press release) }\end{array}$ \\
\hline News & $\begin{array}{l}\text { Letting people know about a library event either through a } \\
\text { comment or a flyer }\end{array}$ \\
\hline Opinion & Complaints, discussions, advocating change \\
\hline Question & A student asking a library-related question \\
\hline Inform & A student providing library-related reference assistance \\
\hline
\end{tabular}

Finally, the text of the library posts and comments were examined to ascertain whether the students received thorough and correct responses to their library queries.

\section{Analysis of Data}

The Know It All Guide featured a total of 146 posts about the library during the fall 2013 and spring 2014 semesters (fall: 77 posts; spring: 69 posts). These library-related posts received a total of 838 likes (fall: 331 likes; spring: 507 likes) and 794 comments (fall: 454 comments; spring: 340 comments). However, among these 794 comments on library posts, only 195 comments were actually relevant to the library (fall: 58 library-specific comments; spring: 137 library-specific comments).

Based on an estimate of total Know It All Guide posts and likes, library posts represented 2.1 percent of all posts and 2.1 percent of all likes on the group wall. The comments on library posts were an estimated 4.2 percent of all the Know It All Guide comments, but the library-related comments represented only 1 percent of the total estimate comments on the Facebook group wall during the period analyzed. While the original post may have been library related, we found that students would frequently turn to tangential discussions on nonlibrary subjects (see table 3 ).

The quantity of student feedback on library-related content varied greatly postto-post and from the fall to spring semesters. The fall semester had an average of 4 likes per library post, while the spring semester showed a higher level of engagement with an average of 7 likes per library post. The range of likes was dramatic. During the fall 2013 semester, one library post, featuring a new health food snack machine installed in the library, generated a total of 41 likes. Likewise, during the spring 2014 semester, a Red Bull scavenger hunt in the library during exam week generated a grand total of 99 likes. 


\begin{tabular}{|l|c|c|c|c|}
\hline \multicolumn{5}{|c|}{ TABLE 3 } \\
\hline & $\begin{array}{c}\text { 2 Week Sample } \\
\text { Know It All } \\
\text { Guide }\end{array}$ & $\begin{array}{c}\text { Know It All } \\
\text { Guide Fall } \\
\text { and Spring } \\
\text { Estimated } \\
\text { Total }\end{array}$ & $\begin{array}{c}\text { Total Library } \\
\text { Fall and } \\
\text { Spring }\end{array}$ & $\begin{array}{c}\text { Percent of } \\
\text { Library on the } \\
\text { Know It } \text { All } \\
\text { Guide }\end{array}$ \\
\hline Posts & 442 & 7,072 & 146 & $2.1 \%$ \\
\hline Likes & 2,544 & 40,704 & 838 & $2.1 \%$ \\
\hline Comments & 1,181 & 18,896 & 794 & $4.2 \%$ \\
\cline { 1 - 2 } Lib. Comments & & & 195 & $1 \%$ \\
\hline
\end{tabular}

As shown in table 4, there was a difference between the fall and spring in terms of the number of student comments on library posts, with spring semester characterized by a greater level of discussion. The number of comments on library posts varied as well, but not as dramatically as the likes. During the fall semester, a YouTube video featuring a time-lapse video of a Day in the Life of the Library (http://www.youtube.com/ watch?v=2xeEqMHvRE0) garnered eight comments, the highest number for that semester. In the spring semester, the highest number of comments (17) was associated with a post about a student couple having sex in the library; these comments primarily consisted of students asking for and providing more information and a ribald array of puns and jokes.

During the fall 2013 semester, 14 percent of the posts had a picture, 5 percent had a hyperlink, and 20 percent had a flyer; of the library posts in the spring 2014 semester, 17 percent had a picture, 9 percent had a hyperlink, and 25 percent had a flyer. Library posts in the spring 2014 semester had a slight increase in the proportion of multimedia content. For both semesters, a library post had an average of 5.7 likes; a library post with text had an average of 5.2 likes; a library post with a hyperlink averaged 1.6 likes; a library post with a flyer generated an average of 3 likes; while a library post with a picture averaged 13 likes. Thus, the increase in the proportion of picture content during the spring semester posts might partially explain the higher level of engagement.

Library-related posts by a student had an average of 7 likes per post, while libraryrelated posts by a library employee had an average of 3 likes per post. During the fall, 73 percent of the library posts were created by students; by contrast, during the spring, 67 percent of the posts were created by students. Spring has a lower level of student post origination but a higher level of engagement with these library posts. Library contests and scavenger hunts in the library generated a higher level of feedback. The library's Halloween Costume Contest received 3 likes and 3 comments, the READ poster

\section{TABLE 4}

Mean, Median, Mode, and Range of Library Likes and Comments

\begin{tabular}{|l|c|c|c|c|}
\hline & $\begin{array}{c}\text { Fall (331 } \\
\text { Likes on 77 } \\
\text { posts) }\end{array}$ & $\begin{array}{c}\text { Spring (507 } \\
\text { Likes on 69 } \\
\text { posts) }\end{array}$ & $\begin{array}{c}\text { Fall (58 Lib.-related } \\
\text { Comments on 77 } \\
\text { posts) }\end{array}$ & $\begin{array}{c}\text { Spring (137 Lib.- } \\
\text { related Comments } \\
\text { on 69 posts) }\end{array}$ \\
\hline Mean & 4.3 & 7.2 & 1.3 & 2 \\
\hline Median & 1 & 4 & 0 & 1 \\
\hline Mode & 0 & 0 & 0 & 0 \\
\hline Highest \# & 41 & 99 & 8 & 17 \\
\hline
\end{tabular}




\begin{tabular}{|l|c|c|c|}
\hline \multicolumn{3}{|c|}{ TABLE 5 } \\
& $\begin{array}{c}\text { Fall Student } \\
\text { Posts }\end{array}$ & $\begin{array}{c}\text { Spring Student } \\
\text { Posts }\end{array}$ & $\begin{array}{c}\text { Combined Semester } \\
\text { Student Posts }\end{array}$ \\
\hline Monday & $20 \%$ & $23 \%$ & $21 \%$ \\
\hline Tuesday & $11 \%$ & $13.5 \%$ & $12 \%$ \\
\hline Wednesday & $21 \%$ & $13.5 \%$ & $18 \%$ \\
\hline Thursday & $20 \%$ & $13.5 \%$ & $17 \%$ \\
\hline Friday & $7 \%$ & $18 \%$ & $12 \%$ \\
\hline Saturday & $12 \%$ & $5 \%$ & $9 \%$ \\
\hline Sunday & $9 \%$ & $13.5 \%$ & $11 \%$ \\
\hline
\end{tabular}

contest received 11 likes and 1 comment, while the scavenger hunt for the Red Bull in the library stacks generated 111 likes and 12 comments. These levels of feedback are higher than the average levels of noncontest feedback.

During the fall semester, student-posted library-related comments occurred most frequently on 1) Wednesdays, 2) Mondays and Thursdays (tied), and 3) Tuesdays. During the spring semester, students posted most frequently on 1) Mondays, 2) Wednesdays, and 3) Thursdays (see table 5).

\section{Comparison to NPML In-House Reference Questions}

The types of reference questions between those submitted to the Know It All Guide were very different from those fielded by the NPML service desks. In both the fall and spring semesters, the Know It All Guide was heavily dominated by general types of library posts ( $84 \%$ in the fall and $91 \%$ in the spring). In contrast, while the General questions were still the largest category at the library service desks, close to 50 percent of the other questions were categorized as either Technical, Basic instruction, or Research types of questions, as illustrated in table 6 . The second noteworthy feature of table 6 is the difference between the fall and spring semesters on the Know It All Guide. In the fall semester, 4 percent of the library-related content were Basic library instruction questions (such as how to find a book) and 2 percent were Research-based questions (such as how to format a paper using APA citation style and how to find peer-reviewed articles). In contrast, during spring 2014, the students did not ask a single library instruction or research type of question on the Know It All Guide.

The weekly volume library Facebook posts and comments correlated to the numbers of questions asked at the library service desks with a moderately significant correla-

TABLE 6

Poynter Library Reference Classification on Facebook and Library Service Desks

\begin{tabular}{|l|c|c|c|c|}
\hline $\begin{array}{l}\text { Fall 2013 } \\
\text { Reference Stats }\end{array}$ & $\begin{array}{c}\text { Fall 2013 } \\
\text { Desk \% }\end{array}$ & $\begin{array}{c}\text { Fall 2013 } \\
\text { Facebook \% }\end{array}$ & $\begin{array}{c}\text { Spring 2014 } \\
\text { Desk \% }\end{array}$ & $\begin{array}{c}\text { Spring 2014 } \\
\text { Facebook \% }\end{array}$ \\
\hline General & $56.3 \%$ & $84 \%$ & $57 \%$ & $91 \%$ \\
\hline Technical & $20.3 \%$ & $10 \%$ & $21 \%$ & $9 \%$ \\
\hline Basic & $18.4 \%$ & $4 \%$ & $18 \%$ & 0 \\
\hline Research & $5 \%$ & $2 \%$ & $4 \%$ & 0 \\
\hline TOTAL & $100 \%$ & $100 \%$ & $100 \%$ & $100 \%$ \\
\hline
\end{tabular}


tion of .43 at a $p<0.05$ level of confidence. As seen in table 7, both the library reference statistics and the library comments on the Know It All Guide display peak volumes: 1) at the start of the semester; 2 ) roughly midsemester representing midterms; and 3) at the end of the semester during the final two weeks. It should be noted that the library service desk is relatively quiet during exam week (in terms of volume of questions), while the Know It All Guide was busy.

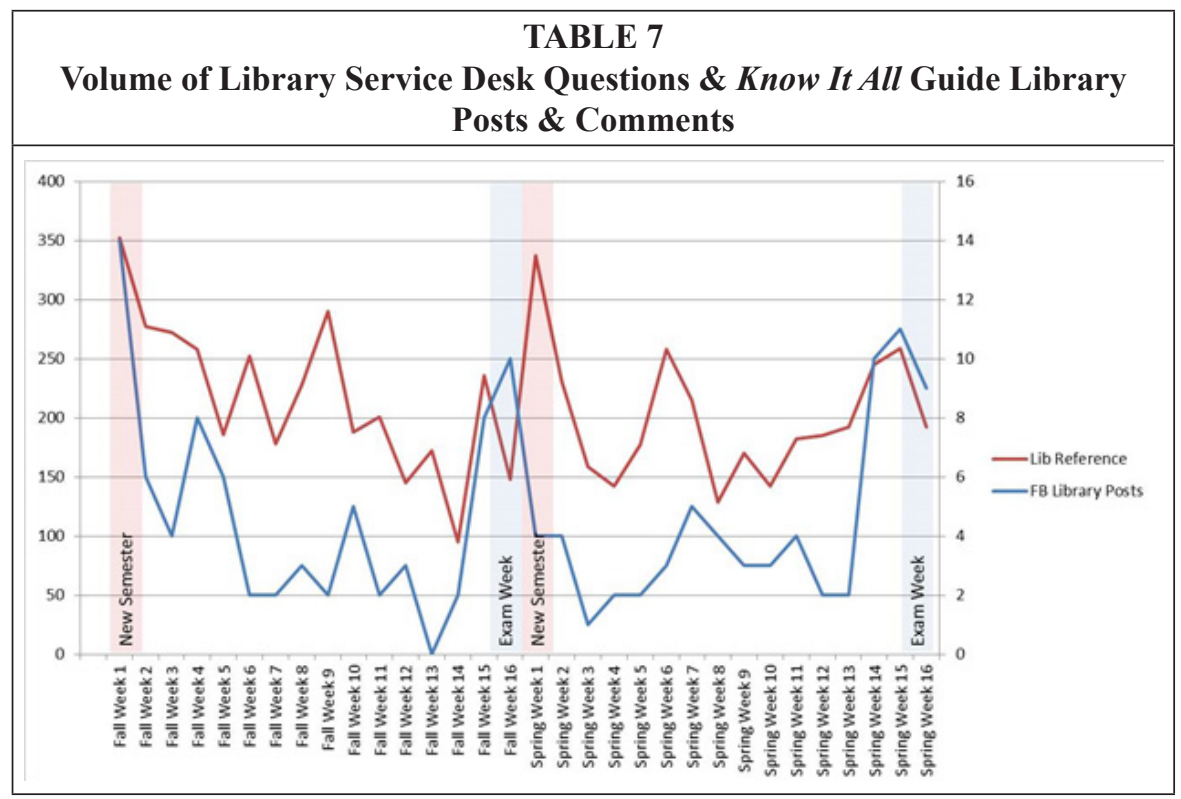

Our content analysis found that students posted and commented on the Know It All Guide to: 1) provide other students with information about the library -in other words, providing reference assistance $(28.7 \%) ; 2$ ) ask questions about the library $(22.4 \%) ; 3)$ express their opinions $(21.8 \%) ; 4$ ) disseminate library news and events (a category dominated primarily by library employees) $(12.5 \%) ; 5)$ demonstrate their virtual participation in library events $(8.7 \%)$; and 6 ) broadcast multimedia content, a category equally done by students and librarians (5.9\%). Table 8 provides examples of each of these types of content categories from the Know It All Guide.

Interestingly, the largest percent of students' posts and comments were students providing general reference assistance. Examining the student questions by the Poynter Library classification scheme, we find that General library questions (84\%) and Technical library questions (73\%) were answered. Only 66 percent of the Basic Instruction questions were answered, and none of the library Research questions were answered. Yet, if the students were providing general and technical reference assistance to their colleagues, this begs the question of whether they provided the correct answer. For General and Technical questions, the answer is yes. Some questions needed only one response. For example:

Student 1 Question: Is there a scanner on campus? I need to send some physical documents to a professor abroad.

Student 2 Response: The library has a scanner.

More frequently it took many student comments built upon each other to successively provide more thorough answers to the original question. For example: 


\begin{tabular}{|c|c|c|}
\hline \multicolumn{3}{|l|}{$\begin{array}{c}\text { TABLE } 8 \\
\text { Type of Information Shared on Facebook }\end{array}$} \\
\hline Question & Count & $\%$ \\
\hline $\begin{array}{l}\text { Examples: } \\
\text { 1. Can someone help me convert my video to mp4? I'm on the library } \\
\text { computers and it doesn't seem to be working. } \\
\text { 2. Does anyone know who I would need to talk to about possibly turning } \\
\text { our library into } 24 \text { hrs? Or if it would even be on the table as an option? } \\
\text { 3. Does anyone know what time the library opens tomorrow morning? } \\
\text { Thanks. }\end{array}$ & 72 & $22.4 \%$ \\
\hline Inform & 92 & $28.7 \%$ \\
\hline $\begin{array}{l}\text { Examples: } \\
\text { 1. In the library, in the children's back room, there are little "movie } \\
\text { rooms." No one is ever in there. } \\
\text { 2. The library has said they would love to have extended hours, though } \\
\text { they cannot show the demand! We as students need to use it more to } \\
\text { have these increases! } \\
\text { 3. You check out a key with your student ID and typically the room } \\
\text { checkout is for } 3 \text { hrs but it may be shorter due to midterms. }\end{array}$ & & \\
\hline Opinion & 70 & $21.8 \%$ \\
\hline $\begin{array}{l}\text { Examples: } \\
\text { 1. Hey, whoever wins the election should make the library not close at } 5 \\
\text { pm on the weekends (Well Saturday and Friday). Thanks. } \\
\text { 2. Really, guys? We get private rooms to study in and someone was stupid } \\
\text { enough to write on the wall!! We are not in elementary school, geez- } \\
\text { we're in college. Seriously in pen too! Grow up. } \\
\text { 3. I like to spread too. The third floor of the library has been my second } \\
\text { home the last few weeks. }\end{array}$ & & \\
\hline News & 40 & $12.5 \%$ \\
\hline $\begin{array}{l}\text { Examples: } \\
\text { 1. Get into the Olympic spirit and come hear the stories from our local } \\
\text { Olympians. Tues Jan } 14 \text { at the Library. } \\
\text { 2. Oh the Cuteness!! The library's going to the dogs for mid-terms. Mark } \\
\text { your calendar: Feb } 24,3: 30-4: 30 \text {. } \\
\text { 3. Today at the Library: Students from the Florida Studies program talk } \\
\text { about their research-Discovering La Florida in the Oldest Diocesan } \\
\text { Archive of America by (STUDENT NAME \& William Harvard, Sr. } \\
\text { And St. Petersburg's Mid-Century Modern Pier by (STUDENT NAME) }\end{array}$ & & \\
\hline Multimedia Broadcasting & 19 & $5.9 \%$ \\
\hline $\begin{array}{l}\text { Examples: } \\
\text { 1. Longboards, Longboards everywhere (picture of longboards in library) } \\
\text { 2. In case you missed the talk in the Library on the 19th, here is the link } \\
\text { to the Panel Discussion by Dr. D... and Dr. S... (link to video on } \\
\text { YouTube) } \\
\text { 3. And the winners in for the READ poster contest are: Best Overall } \\
\text { poster goes to Game of Thrones, Best Student Poster goes to Lemony } \\
\text { Snicket, Best Faculty/Staff poster goes to Dog Genome. Thank you to } \\
\text { everyone that entered as a contestant and voted in the contest (pictures } \\
\text { from contest) }\end{array}$ & & \\
\hline
\end{tabular}




\begin{tabular}{|c|c|c|}
\hline \multicolumn{3}{|l|}{$\begin{array}{c}\text { TABLE } 8 \\
\text { Type of Information Shared on Facebook }\end{array}$} \\
\hline Virtual Participation & 28 & $8.7 \%$ \\
\hline $\begin{array}{l}\text { Examples: } \\
\text { 1. Happening now! } \\
\text { 2. Featuring the most excellent (STUDENT NAME)! } \\
\text { 3. During finals if you have library questions, like their (Facebook) page } \\
\text { at Nelson Poynter Library! }\end{array}$ & & \\
\hline
\end{tabular}

Student 1 Question: Does anyone have any suggestions for a good quiet place to study on campus

Student 2 Response: Library?

Student 3 Response: Get a study room in the library. You go to the front desk and they scan your ID. You can usually renew the room as well if there isn't a high demand (like during finals). There are white boards in them you can use for math and they will give you dry erase markers and an eraser if you ask!

Student 4 Response: The 3rd floor of the library is a quiet zone

Student 5 Response: 3rd floor of library

As we can see from this discussion, four different students responded, and collectively they provided the correct and complete answer to the original student's question. In all cases, the student responses to the Basic Instruction questions were a referral to the library, librarian, or library catalog. As for the library Research questions, none of these posts on the Know It All Guide elicited any type of response at all.

Library hours were a hot topic throughout the year, but particularly during the Student Government (SG) election. The following conversational thread is emblematic of this issue, the combination of students voicing their concerns, other students contributing information, and the current SG representatives and candidates joining the discussion.

Student 1: Why can't the library be open earlier and close later on weekends? (Links to the names of 2 Student Government Candidates), will this be an upcoming change I'm hoping?

Student 2 (current SG President): The library has said they would love to have extended hours, though they cannot show the demand! We as students need to use it more to have these increases!

Student 1: Yeah, understandable. I just have a lot of studying today for example and I heard it's only open from 12-7. And I feel like a lot of people study on Sundays.

Student 2 (current SG President): AMEN Hallelujah I agree! Packing the library from now till the end might make a difference!

Student 3 (1st SG Candidate): We'll definitely be working on it. We'll also be meeting with her to see what we can do about it. I will quote (the library Dean) on this one when she came into a General Assembly meeting, she said if students want the hours increased as well as opened later they have "to do it with their feet." Which means we have to get more students in the library at all times. If you want it opened later more students need to go into the library later. They count every person that goes into the library. Right now I don't know the stats although honestly there aren't enough students in there. The library hears how it should be opened more although they don't see enough students. I hope this helped.

Student 1: Yes it does. Definitely need more people in the library then. But I understand what you mean. 
Student 4: Literally pack the library and then just chill until closing hours.

Student 5 (2nd SG Candidate):They have tracked the amount of people that go in and out and of people that are there the amount of people not outweigh the cost of that entire building being open.

Student 1: I'm down. The library is one of my favorite parts of this campus.

Student 6: The library hours are a big pet peeve of mine. Sometimes the only time I have to study is closer to closing time and it's not worth it for me to drive all the way to campus to only be able to use the library for a couple of hours. When I get in to a groove I need to keep going, not have to pack up my stuff and find a new place to go. And the opening hours on Sundays are just... : ( Past semesters I have been able to be in there during the day all day, but this semester it just worked out I don't have the time during the day so I end up just shutting myself in my room and hoping no one bothers me.

Student 7: Agreed I don't understand how the campus gym is open 6am-11pm but the library is only open from 8am-10pm on weekdays... and on weekends the time differential is even worse.

Student 5 (2nd SG Candidate): They are funded differently, you directly pay for the gym.

Again, we see that the students are responding to their peers' questions and discussing the issue. Additionally, the current Student Government President and the SG Presidential candidates had all obviously met with and discussed this issue with the Library Dean. While the librarians did not comment on this post, the library's policies and procedures were still effectively disseminated by the Student Government representatives from their real-world contact with the Library Dean.

\section{Discussion}

Past research has suggested that students prefer a separation between their personal and academic lives on Facebook. ${ }^{26}$ On the Know It All Guide, we found that students seamlessly moved between their personal spheres (jobs, activities, relationships, and the like) and their academic ones (courses, library, graduation, and such). Rather than distinct, the students integrated their peers and the librarians as resources for general library information. Inversely, the comments demonstrated that the students seamlessly integrated the library into their social lives (meeting with friends, participating in contests, and so on) and their academic needs (location to study, providing research assistance).

The librarians primarily used the Facebook group to promote library events. With regard to the library, the students in contrast used it for entirely different purposes: namely asking for quick general library information from their peers, answering their colleagues' questions, discussing issues that are important to them, and encouraging their fellow students to participate in the library events. While past research has found that students were more likely to receive information passively on library Facebook pages, we found that the students proactively asked and responded to library questions. ${ }^{27}$ The difference found in our case study is that students were asking each other rather than consulting a librarian, a process that probably increased their level of comfort and removed any connotations of discomfort from formality or authority intrusion.

In contrast to the proactive responses to general library questions, the students' basic instructional and in-depth research questions were treated very differently by their peers. For the basic library research questions, when they actually elicited a response, the students referred their peers to the library catalog or to the library help desks rather than trying to directly answer the questions. This is similar to the findings by Griffin and Taylor, where the librarians on the library Facebook page 
primarily referred the students to the physical library rather than directly answering the questions. ${ }^{28}$ However, in this case it is the students themselves who are referring their peers to the library. The few in-depth research questions asked on the Know It All Guide received no response at all.

Additionally, all of these basic and in-depth library research questions were asked in the fall semester, while these types of questions were not asked during the spring semester on the Know It All Guide. We would like to believe that the students learned from the fall to the spring semester that perhaps the Know It All Guide was not the best forum for posing serious research questions. Whether they learned this from the student referrals, the lack of Facebook response, or the experience with the library's traditional reference and research support services does not matter. However, we consider the drop of basic and in-depth research student questions from the fall to the spring semester in the Know It All Guide a good thing since librarians are best trained to help the students with these types of questions.

From the above results, we have generated several recommendations for other academic libraries on how to best manage their Facebook outreach. These focus on targeting peak times, using naturalistic photos, and accepting and facilitating student peer-to-peer support.

Librarians have only so much time and capacity that they can devote to social media. Furthermore, among the vast quantity of posts on these Facebook groups, library-related topics can easily be missed. Thus, determining when students are most active on Facebook can help focus the librarian's efforts regarding when they will have the most impact. Overall, students' library posts occurred most frequently on Mondays and Wednesdays on the Know It All Guide. The number of weekend library-related posts was comparatively small. Thus, disseminating library information during the workweek is sufficient, as this is when the students are most engaged in academically related social media activity. Librarians can also focus on the peak times of the semester, namely at the beginning of the semester, during midterms, and a few weeks before and during final exams. This is when the students have the most questions about library services and resources. This rise in questions echoed the rise in questions at the library's in-house service desks. The semester seasonality of when students need help learning about the institution, working on major assignments and research papers, and studying for exams reflects the best times to disseminate library information in the Facebook group pages.

With regard to library events, a peak time to post to the Facebook group is when the events are happening. This synchronous posting of pictures helps increase visibility and virtual participation. As an outreach strategy, when a library event is starting, the librarian should plan on taking pictures at the very start and quickly posting them to the Facebook group. This strategy encourages students to spontaneously decide to attend a library event. Perhaps students are between classes, at loose ends, or just needing a break. If so, synchronous posting of pictures informs the students and encourages spontaneous attendance.

Students responded to visual stimuli in the Know It All Guide, but it was done in a participatory manner unique to social media. Library contests were also particularly engaging to the students. The Red Bull scavenger hunt, the Halloween Costume contest, and the READ poster contests generated the highest levels of student feedback from all of the library-related posts. Library contests, whether in the library or participating through voting in the Facebook groups, can be an effective marketing strategy to encourage library engagement and participation.

Photographs also increased student responses; in particular, the pictures of food, snacks, and caffeine generated a lot of appreciation. Candid unmediated pictures in 
and of the library are a particularly effective means of library marketing on Facebook. We know that students respond more to their fellow students, and we know that students respond more to pictures on Facebook. When the library posts combined these two elements, particularly when the students uploaded their own pictures of the library or linked their friends' names to a library event while it was going on, the students effectively did the marketing for the library. The Facebook tags and comments act as word-of-mouth advertising, traditionally an effective marketing tool, in our social media age. When a popular student, well known on campus for organizing many social events, called for people to like the library's Facebook page, the number of library Facebook page likes immediately bumped up within the next 24 hours. The library's social cachet and audience is clearly superior when it is student-to-student rather than librarian-to-student. An outreach strategy that uses photographs with a relaxed, naturalistic depiction enables students to tag each other and lets students rebroadcast library events and resources to a much broader audience. This may be an area where the library can use student workers to post on Facebook rather than librarians. These students would be knowledgeable about library-related questions and could respond with accurate information, or they could advocate for the library in a more natural conversation.

One of the biggest concerns prior to this research was the accuracy and value of student responses to students' library-related questions. It is notable that students provided reference assistance for quick and easy library information and technical questions on the Know It All Guide. Additionally, they were also providing correct library information for these general and technical library questions. Often these library questions would get multiple responses from multiple students. Over the range of a comment thread, the original student asking the question would get a very thorough answer. It is through this qualitative analysis of student Facebook narrative threads that we are able to illustrate library impact on student lives, a measure of social media impact that Glazer argues is of particular significance. ${ }^{29}$

Furthermore, students posted library questions on the Know It All Guide throughout the day and night. For a librarian to effectively monitor the Facebook group, he or she would have to constantly check the Facebook page. We heartily agree with Jacobson and Gerolimos that this constant reference surveillance is not a good use of library employee effort. ${ }^{30}$ We find it a positive development that the students were doing general information reference work for the library - and doing a good job at it.

A major caveat, however, is that the library must still engage students in the real world for virtual outreach to be successful. As we can learn from the quoted conversation thread on library hours, the Student Government representatives, having originally met face-to-face with the library Dean, were subsequently able to broadcast the library's policies and procedures to their fellow student on the Facebook group. If the library dean had not originally met with the SG representatives in the real world, we are sure the contents of this conversation in the Facebook realm would have been less informative and possibly characterized the library in a less positive light. Thus, the library's in-person outreach efforts to student government, and to the student body in general, serve as a foundation for the virtual conversations on the Know It All Guide. These conversations communicate the library's message to the students and enable the students to further help disseminate the information in the virtual realm.

\section{Conclusion}

This study is designed to help librarians learn the best methods and times to engage in library outreach on Facebook. If we as a profession are interested in going where the students are, then one place they are is on student-run Facebook groups, seam- 
lessly transferring information, discussions, and feedback between their academic and personal lives. Virtual library outreach complemented face-to-face outreach, and the inverse was equally true. Synchronous, visual, and naturalistic outreach on social media sites drives in-house library participation. Likewise, traditional face-to-face library outreach is necessary to enable online students to provide accurate, thorough, and positive library information.

Of equal concern to librarians is the question of value of this virtual engagement to the core mission of an academic library. Academic libraries host in-house library events, under the assumption that these events contribute to student learning, engagement, and retention. Through our content analysis, we can see that students are participating virtually in library events, watching videos, connecting to resources, and actively discussing library policies and procedures in a virtual forum. Currently, quantitative statistics in the form of fans and likes demonstrate a low level of engagement; but this quantitative information only tells part of the story. If this low level of virtual engagement becomes the path through which students learn about the library and become funneled to deeper levels of research and instruction help, then qualitative research into the symbiotic relationship between virtual and real-world library outreach needs to be further studied and appreciated.

\section{Notes}

1. Matt Hicks, “Giving You More Control," Notes by Facebook (Blog, Oct. 6, 2010, 2:13 p.m.), available online at https://www.facebook.com/notes/facebook/giving-you-more-control/434691727130 [accessed 22 January 2015].

2. Cisco, "Web 2.0," Higher Education Trends and Statistics (2008), available online at http:// www.cisco.com/web/about/ac79/edu/trends/issue01.html [accessed 18 March 2014].

3. Christy MK Cheung, Pui-Yee Chiu, and Matthew KO Lee, "Online Social Networks: Why Do Students Use Facebook?" Computers in Human Behavior 27, no. 4 (2011): 1337-43; David Bietila, Chris Bloechl, and Elizabeth Edwards, "Beyond the Buzz: Planning Library Facebook Initiatives Grounded in User Needs," in ACRL National Conference (2009), 135-42, available online at http:// dspace.wrlc.org/handle/1961/5136 [accessed 27 February 2014].

4. Melanie Chu and Yvonne Nalani Meulemans, "The Problems and Potential of MySpace and Facebook Usage in Academic Libraries," Internet Reference Services Quarterly 13, no. 1 (2008): 69-85 [accessed 27 February 2014]; Dianna E. Sachs, Edward J. Eckel, and Kathleen A. Langan, "Striking a Balance: Effective Use of Facebook in an Academic Library," Internet Reference Services Quarterly 16, no. 1/2 (2011): 35-54.

5. Ruth Sara Connell, "Academic Libraries, Facebook and MySpace, and Student Outreach: A Survey of Student Opinion," portal: Libraries and the Academy 9, no. 1 (2009): 25-36; Kenneth J. Burhanna, Jamie Seeholzer, and Joseph Salem Jr., "No Natives Here: A Focus Group Study of Student Perceptions of Web 2.0 and the Academic Library," Journal of Academic Librarianship 35, no. 6 (2009): 523-32.

6. Meredith Farkas, "Going Where Patrons Are: Outreach in MySpace and Facebook," American Libraries 38, no. 4 (2007): 27.

7. Gang Wan, "How Academic Libraries Reach Users on Facebook," College E Undergraduate Libraries 18, no. 4 (2011): 307-18.

8. Connell, "Academic Libraries, Facebook and MySpace, and Student Outreach," 31.

9. Sachs, Eckel, and Langan, "Striking a Balance," 10.

10. Wan, "How Academic Libraries Reach Users on Facebook," 314.

11. Sachs, Eckel, and Langan, "Striking a Balance," 2; Terra B. Jacobson, "Facebook as a Library Tool: Perceived vs. Actual Use," College E Research Libraries 72, no. 1 (2011): 79-90; Harry Glazer, "Clever Outreach or Costly Diversion? An Academic Library Evaluates Its Facebook Experience," College E Research Libraries News 70, no. 1 (2009): 11-19; Harry Glazer, “Likes Are Lovely, but Do They Lead to More Logins? Developing Metrics for Academic Libraries' Facebook Pages," College $\mathcal{E}$ Research Libraries News 73, no. 1 (2012): 18-21.

12. Z. David Xia, "Marketing Library Services through Facebook Groups," Library Management 30, no. 6/7 (2009): 469-78; Nancy Kim Phillips, "Academic Library Use of Facebook: Building Relationships with Students," Journal of Academic Librarianship 37, no. 6 (2011): 512-22; Glazer, 
"Clever Outreach or Costly Diversion?" 12; Glazer, "Likes Are Lovely, but Do They Lead to More Logins?" 19.

13. Jacobson, "Facebook as a Library Tool," 86.

14. Sachs, Eckel, and Langan, "Striking a Balance," 14; Chu and Meulemans, "The Problems and Potential of MySpace and Facebook Usage," 77; Connell, "Academic Libraries, Facebook and MySpace, and Student Outreach," 33.

15. Melanie Griffin and Tomaro I. Taylor, "Of Fans, Friends, and Followers: Methods for Assessing Social Media Outreach in Special Collections Repositories," Journal of Web Librarianship 7, no. 3 (2013): 255-71.

16. Gary Collins and Anabel Quan-Haase, "Are Social Media Ubiquitous in Academic Libraries? A Longitudinal Study of Adoption and Usage Patterns," Journal of Web Librarianship 8, no. 1 (2014): 48-68; Jacobson, “Facebook as a Library Tool," 88; Glazer, "Likes Are Lovely, but Do They Lead to More Logins?" 18.

17. Wan, "How Academic Libraries Reach Users on Facebook," 314; Collins and Quan-Haase, "Are Social Media Ubiquitous in Academic Libraries?" 57; Glazer, "Likes Are Lovely, but Do They Lead to More Logins?" 20.

18. Ming-Hsin Phoebe Chiu and Yi-Ying Lin, "Virtualizing Library Processes and Interactions: A Content Analysis of Library Facebook Profiles," (2012), available online at http://docs.lib.purdue. edu/iatul/2012/papers/20/ [accessed 14 March 2014].

19. Glazer, "Likes Are Lovely, but Do They Lead to More Logins?" 20.

20. Chiu and Lin, "Virtualizing Library Processes and Interactions," 5; Michalis Gerolimos, "Academic Libraries on Facebook: An Analysis of Users' Comments," D-Lib Magazine 17, no. 11 (2011): 4 .

21. Chiu and Lin. "Virtualizing Library Processes and Interactions," 12.

22. Gerolimos, "Academic Libraries on Facebook," 5.

23. Xia, "Marketing Library Services through Facebook Groups," 476.

24. A. Starling, "Facebook Forum Is Helpful but Dramatic," Crow's Nest 48, no. 27(2014).

25. Debra G. Warner, "A New Classification for Reference Statistics," Reference E User Services Quarterly (2001): 51-55; Deborah B. Henry and Tina M. Neville, "Testing Classification Systems for Reference Questions," Reference E User Services Quarterly 47, no. 4 (2008): 364-73.

26. Burhanna, Seeholzer, and Salem, "No Natives Here," 527 ; Chu and Meulemans, "The Problems and Potential of MySpace and Facebook Usage in Academic Libraries," 77; Connell, "Academic Libraries, Facebook and MySpace, and Student Outreach," 31; Sachs, Eckel, and Langan, "Striking a Balance," 10.

27. Sachs, Eckel, and Langan, "Striking a Balance," 14; Chu and Meulemans, "The Problems and Potential of MySpace and Facebook Usage in Academic Libraries," 82; Connell, "Academic Libraries, Facebook and MySpace, and Student Outreach," 33.

28. Griffin and Taylor, "Of Fans, Friends, and Followers," 266.

29. Glazer, "Likes Are Lovely, but Do They Lead to More Logins?" 19.

30. Jacobson, "Facebook as a Library Tool," 86; Gerolimos, "Academic Libraries on Facebook," 10. 